\title{
It is windy in Denmark: Does market integration suffer?
}

\author{
Nuno Carvalho Figueiredo a, c, *, Patrícia Pereira da Silva b, c, Pedro A. Cerqueira b, d \\ ${ }^{a}$ Energy for Sustainability Initiative, University of Coimbra, Portugal \\ ${ }^{\mathrm{b}}$ Faculty of Economics, University of Coimbra, Av. Dias da Silva, 165, 3004-512 Coimbra, Portugal \\ c INESC Coimbra, DEEC, Rua Sílvio Lima, Pólo II, 3030-290 Pinhal de Marrocos, Coimbra, Portugal \\ d GEMF, Grupo de Estudos Monetários e Financeiros, Coimbra, Portugal
}

\section{A R T I C L E I N F O}

\section{Article history:}

Received 30 October 2015

Received in revised form

19 March 2016

Accepted 10 May 2016

Available online 10 June 2016

\section{Keywords:}

Market splitting

Renewable energy

Non-parametric models

\begin{abstract}
A B S T R A C T
Some benefits of spot electricity markets integration include the optimization of renewable power, increasing transmission grid security and the decreasing need for internal generation reserves. The high penetration of wind power is known to have a clear influence on price convergence between electricity markets joined by market splitting. However, in multiple interconnected markets, cross-border flows can also play a role in the market splitting behaviour. Denmark, with a high penetration of wind power, is clearly the ideal case study. This paper aims to assess the influence of high penetration of wind power on the market splitting behaviour between West and East Denmark, taking into account cross-border electricity flows. This is modelled through logit and non-parametric models, estimating the probability of market splitting occurrence between both Danish bidding areas. Market splitting probability is found to be sensitive to wind power, nevertheless with distinct behaviour according to interconnection congestion configuration. The highest availability of wind power in West Denmark, which can reach a generation share of 1.5 times the demand, requires strong cross-border interconnections to allow the export of the excess generation. Policies governing a joint assessment of the requirements for additional interconnection and wind power expansion plans, should be developed.
\end{abstract}

๑) 2016 Elsevier Ltd. All rights reserved.

\section{Introduction}

The fast expansion of renewable generation, resulting from the transition to a post carbon society, is creating one of the most demanding challenges to transmission grids and their operation [1-5]. In addition, the integration of the European electricity markets through HV (High Voltage) cross-border interconnections, is a substantial part of the European internal energy policy [6,7], aiming to offer numerous advantages under normal operating conditions, such as optimal power station daily production, increasing opportunities for operation with renewable energies, the promotion of competition and enhancement of supply security. However, cross-border interconnections are limited and congestions can arise in multiple operation conditions.

One of the best case studies, considering the high level deployment of wind power and with a long history of electricity market integration through market splitting, is Denmark. Its support to research and technological development of wind power,

\footnotetext{
* Corresponding author. Sustainable Energy Systems, MIT-P, Portugal.

E-mail address: nuno.figueiredo@portugen.com (N.C. Figueiredo).
}

resulted in a strong player in the wind power turbine market, supplying about one third of the world demand for this technology $[8,9]$.

Literature can be found regarding electricity market integration in different geographic areas. US regional electricity markets integration is studied in Refs. [10,11], using spot market electricity prices, the first through cointegration and a vector error correction model and the second through a vector auto-regression model. Electricity market integration in Australia is assessed in Refs. $[12,13]$, through the use of MGARCH (Multivariate Generalized Autoregression Conditional Heteroskedasticity) models, to include time-varying conditional correlation spillovers across electricity markets and better describe price and price volatility interrelationships. Electricity market integration in Europe was assessed by a significant number of studies and these are unanimous in establishing that there is electricity market integration in the North European regional electricity market, the Nord Pool, which is composed currently by Norway, Sweden, Finland, Denmark, Lithuania, Estonia and Latvia. However, by using Markov switching fractional cointegration, Ref. [14] found that cointegration exists only when interconnections between bidding areas are 
not congested in a detailed analysis to the electricity price pairs West Denmark - Norway and East Denmark - Sweden. Furthermore, Ref. [15] used a PCA (Principal Component Analysis), unit root tests and a convergence test based on filtered pairwise price relations of wholesale electricity prices, demonstrating that convergence between both Danish bidding areas and between East Denmark and Sweden had been achieved. However, Ref. [16] through the use of cointegration and unit root analysis, found the Nordic electricity markets not to be integrated with Germany and the Netherlands. In an assessment of European spot electricity markets convergence, Ref. [17] used a fractional cointegration analysis and a MGARCH model, to report that Nord Pool is fractionally cointegrated with the remaining analysed electricity markets (Austria, Belgium, Czech Republic, France, Germany, Greece, Ireland, Italy, Poland, Portugal, Spain, Switzerland, the Netherlands and the UK), and that perfect integration had not been achieved. A summary table regarding the above studies can be found in Appendix B for easier reference.

Also, literature focussing the impact of high penetration of wind power can be found. Highlighted issues in Ref. [18] are: the importance of adequate interconnection and transmission capacities; the capacity incentives for dispatchable power plants; demand management, reduce electricity trading constraints and further research on energy storage technology. Moreover, Ref. [19] highlighted the risk of excessive production, the use of energy storage and exports through interconnections to address balancing issues, appropriate system security and ancillary services; and Ref. [20] stressed the importance of enough dispatchable backup capacity with fast response dynamics, system robustness and reserves to cover uncertainty and/or withstand eventual electrical faults, and adequate transmission grid capacities to transport eventual excess renewable generation; the importance of wind power forecasting, allowing for load management and system balancing, is highlighted in Ref. [21]. Furthermore, Refs. [22-32] all reported some level of decrease on the electricity spot market prices due to the increase in the share of RES-E (renewable energy sources electricity) generation. This is explained due to the almost inexistent marginal costs, associated bidding into the spot electricity market and the resulting merit order of power plant dispatch, which displaces higher marginal cost fossil fuel power plants. The influence of the existing high wind power penetration on the behaviour of electricity price differences was studied for the four ERCOT zones of Texas by Ref. [33], through the use of orderedlogit and log-linear regression models, establishing that high wind power loads in west Texas cause interconnection congestion and electricity price differences with the remaining zones. The RES-E influence on interconnection congestion was also analysed by Ref. [34] for Sicily and the rest of Italy electricity prices, through the use of a time-varying regime switching models and a dynamic probit ruling the transition between regimes, with distinct results as wind power is found to decrease interconnection congestion, which according to the author may be due to wind curtailment practices by the TSO (Transmission System Operator). Moreover, Italy was studied by Ref. [35] through the use of multinomial logit and three stage least square models, reporting that the probability of interconnection congestion increases with high wind power generation exiting a bidding area and decreases with high wind power generation in the destination bidding area. For Iberia, [36] through a non-parametric approach, found that increasing wind power generation, or furthermore, increasing low marginal cost generation has a clear influence on market splitting, increasing its probability.

Therefore, this research aims to assess the influence of high availability of wind power on the market splitting behaviour of the Danish bidding areas in the Nord Pool electricity spot market, taking into account cross-border electricity flows. The leading hypothesis considered in this study is that, in spite of the multiple existing interconnections and associated cross-border flows, wind power generation still influences market splitting in Denmark.

Following [36], expanded to a new multi-interconnected electricity market, logit and non-parametric models are herein used to express the probability response for market splitting of day-ahead spot electricity prices as a function of wind power generation share, electricity demand interconnection cross-border flows and market splitting of adjacent bidding areas. Logit models contribute with preliminary indications on market splitting behaviour, in spite of the known specification limitations. These limitations are subsequently overcome with the use of non-parametric models as demonstrated in Ref. [36].

The structure of the paper is the following: in Section 2 the Danish electricity market characterisation is presented, consisting of a survey of the EU legislative framework and Danish energy policy, an overview of the renewables deployment in Denmark and a brief explanation of the Danish electricity market as part of the Nordic electricity market. Data and model specification used in this study are presented in Section 3, followed by the presentation of the model results in Section 4 and the respective analysis and discussion in Section 5. Section 6 concludes with some recommendations and policy implications.

\section{Danish electricity market characterisation}

\subsection{EU and the Danish energy policy}

The absence of energy natural resources together with the oil crisis of the 1970's drove Denmark into a path of extensive efforts in R\&D (Research and Development) of endogenous energy sources. Within the period until 1990, Denmark developed oil and natural gas production in the North Sea, decreasing its dependency on oil imports. Additionally, energy security of supply was achieved by replacing oil consumption by coal and natural gas, and on the demand side by implementing a challenging energy saving programme [37,38].

Bearing in mind that oil and gas resources are scarce and following the Kyoto accords to reduce $\mathrm{CO}_{2}$ emissions, Danish energy policy turned into the development of renewable energy sources. Nonetheless, the formerly existing Danish energy policy was deemed to be insufficient to achieve the established target of $20 \% \mathrm{CO}_{2}$ emissions reduction by 2005 compared with 1988 , which created the need for the so called "Green Energy Plan", instigating the official "Energy 21" adopted in 1996. This plan comprised of the following measures: switching from electric heating to central heating, improving insulation and low-temperature district heating, utilisation of natural gas in district heating, diffusing the use of biomass, deployment of wind turbines ( $3000 \mathrm{MW}$ by 2015), further stakeholder training and energy conservation [39]. These measures intended to attain the main objective of $\mathrm{CO}_{2}$ reduction by also setting the following sub-targets: $20 \%$ improvement of energy conservation compared with 1994 and 12\%-14\% share of electricity consumption generated from renewable sources. Additionally, the chief goal of achieving $50 \% \mathrm{CO}_{2}$ reduction by 2030 compared with 1998 , would be accomplished by increasing energy conservation to 55\% above 1994 levels and 35\% share of electricity consumption generated from renewable sources [37].

In 2005, the "Energy Strategy 2025" established the vision of total independence from fossil fuels. Targets were established to achieve a reduction of $15 \%$ for fossil fuel usage and keep a static overall energy consumption. Further specific targets were set for energy efficiency (1.25\% annual growth), renewable energy (30\% renewable energy share consumption by 2025) and more efficient new energy technologies (R\&D support of new energy 
technologies). This strategy also depended on efficient markets and specifically on the electricity market where the expansion of transmission networks is fundamental for the supply reliability [40]. Danish energy policy for the years 2008-2011 expanded on previous policies by setting intermediate targets of $20 \%$ consumption share from RES (renewable energy sources) by 2011 and development of offshore wind by 2012 [8].

"Energy Strategy 2050" was launched in 2011, setting the same overall goal of fossil fuel independence, though giving it the deadline of 2050 . The renewable energy share consumption of $30 \%$ was advanced to 2020, supporting and exceeding the EU target of $20 \%$. Furthermore, measures like the electrification of heating systems, industry and transport, or the development of smart grids are part of this strategy. The Energy Agreement reached in March 2012 finally extended and brought Denmark closer to its strategy goals: $35 \%$ consumption share from RES; 50\% electricity demand share from wind power; and 34\% reduction in GHG (Greenhouse Gas) emissions compared to 1990 [38,41].

Danish energy policies were always aligned, if not a step ahead of EU (European Union) own policies. The release of the Council Directive 96/61/EC established common rules for pollution control and prevention and the EU Directive 2003/87/EC established the GHG emission allowance trading scheme. Almost simultaneously, in order to reduce dependency on imported fossil fuels and to allow the reduction in GHG emissions, the EU Directives 2001/77/EC and 2009/28/EC called for the promotion of electricity generation by renewable energy sources. On the electricity market side, the European Directives 96/92/EC, 2003/54/EC and 2009/72/EC established common rules for the various electricity markets in Europe.

\subsection{Renewables deployment in Denmark}

As referred in the above Section, Danish and EU policies for emissions reduction and energy security, together with the related aim to decrease the dependence from fossil fuels, led to the development of RES electricity generation. Given the limited hydropower potential, the Research and Development (R\&D) was mainly focused on wind power and CHP (Combined Heat and Power) [42]. Almost inexistent in 1972, wind power share grew to $20 \%$ in 2008 [43], with some municipalities in West Denmark (DK1) fully supplied by wind power [44]. The main source of renewable electricity generation in Denmark is nowadays wind power, with a share of $51.1 \%$ of the electricity demand in 2014 [45].

Wind power R\&D was enhanced through the establishment of a partnership between public and private institutions, aiming to keep Denmark as a major world player in wind power technology at competitive prices [40]. Additionally, wind power generation development in Denmark has been supported through strong financial support mechanisms, initially by price premiums paid to wind turbine owners and later after 1999 by feed-in tariffs. From 2004 onwards, subsidies were given as supplements to the electricity market price. These subsidies were later increased in 2008 and were limited to a maximum number of full-load operating hours, after which wind power is paid at electricity market prices [46]. A gradual reduction of subsidies to wind power is expected, due to its increasing technological competitiveness and the subsidy expiration of older units [47]. Additional details about wind power financing can be found in Refs. [44,48].

New concerns and challenges of high shares of RES-E are reported both in the technical sense and in the market design. On the technical sense: generation variability and uncertainty, adequate transmission capacity, flexibility and standby of dispatchable generation, electrical system regulation and frequency control, demand side response, RES-E curtailment, energy storage, adequate transmission grid and cross-border interconnections [26,49-51]; and in the market design: electricity market integration, transmission grid and cross-border interconnections cost allocation, intraday and reserve power markets, RES-E financial support schemes and capacity support mechanisms [18,51-53].

As seen in Fig. 1, thermal power generation capacity share is decreasing since 2000, with a steeper fall in 2011, whilst wind power generating capacity share steadily increased during the same period. Therefore, thermal generation was gradually being replaced with wind generation. The absence of hydro and nuclear power generation in Denmark is noteworthy: the former due to the absence of geographic conditions, and the latter, by a parliament resolution not to build nuclear power plants in the country [54]. By the end of 2013, wind power generation capacity reached $4820 \mathrm{MW}$ in Denmark, which is equivalent to a $34.9 \%$ share of installed capacity. Solar power generation capacity share slightly start to

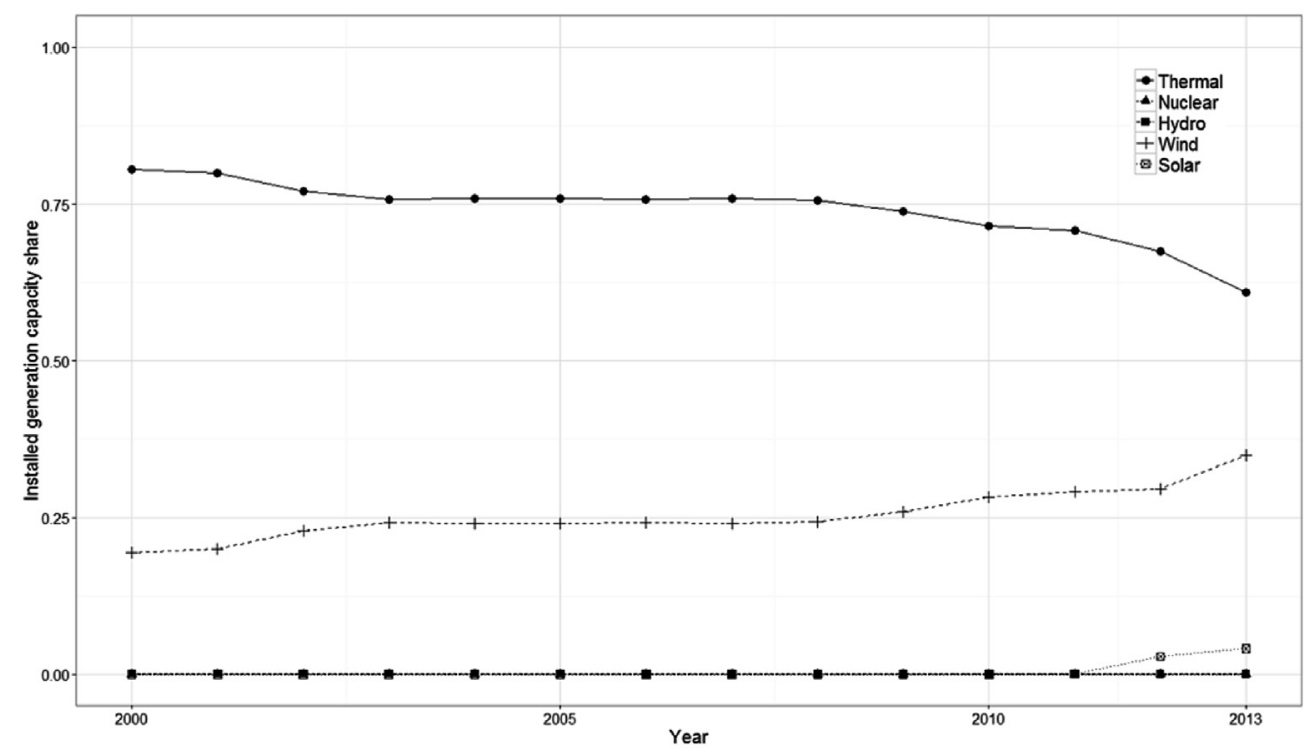

Fig. 1. Installed generation capacity shares of total installed capacity in Denmark [55]. 


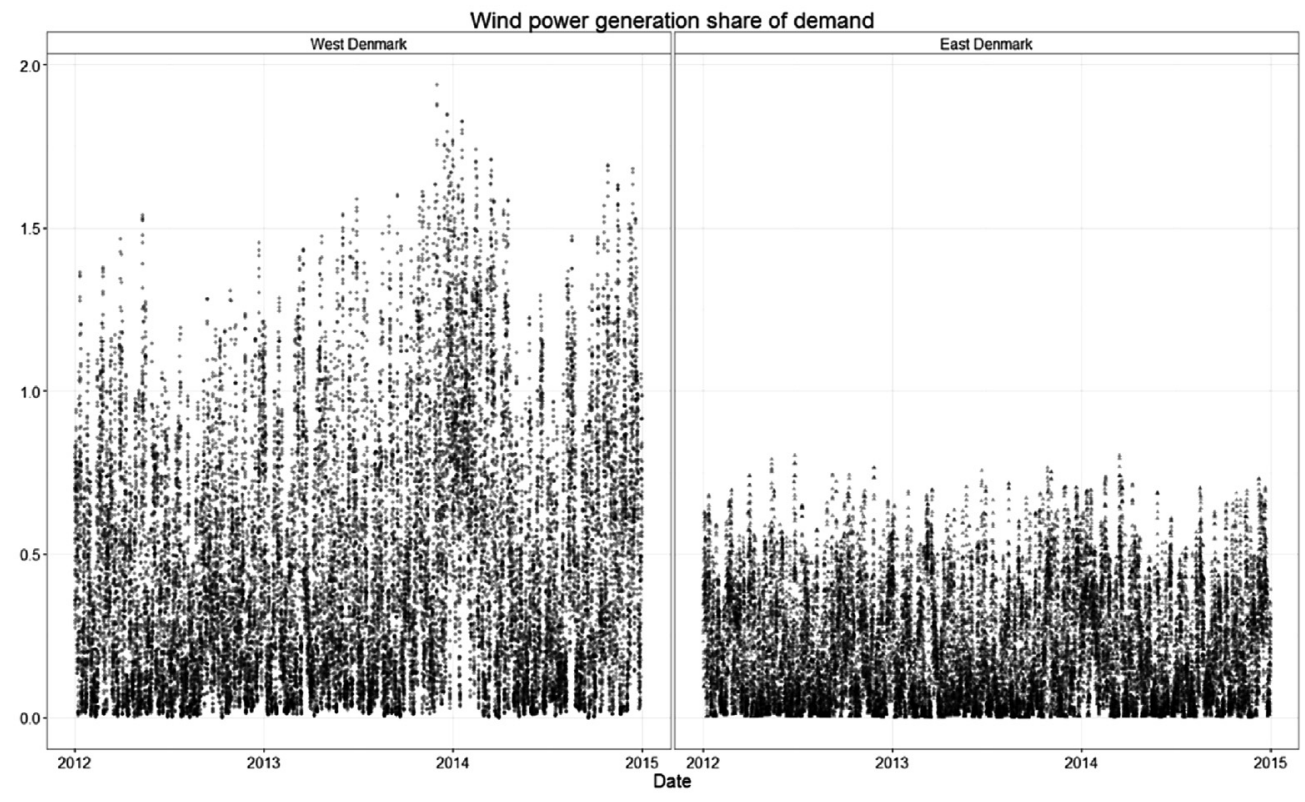

Fig. 2. Wind power generation share of demand in Denmark.

increase after 2011.

When analysing the extracted hourly data, wind power generation share of demand has been, surprisingly in more than a few hourly periods, above 1 in West Denmark (DK1). This means that not only wind generation was able to supply the complete electricity demand in West Denmark (DK1), but also that there was a surplus exported through the existing interconnections. This is not the case for East Denmark (DK2). However, wind power generation share is still quite high, frequently achieving values above 0.5 [45] (see Fig. 2).

\subsection{Denmark in the Nordic electricity market}

The Nordic electricity market, the Nord Pool, is composed by Norway, Sweden, Finland, Denmark, Estonia, Latvia and Lithuania. These countries are then sub-divided by bidding areas, taking into account transmission system capacities and constraints. The Nord Pool was established in 1996 with a joint Norwegian-Swedish power exchange, after the deregulation of the Norwegian electricity market in 1991. To complete the adhesion of the northern European countries, Finland joins Nord Pool in 1998 followed by Denmark in 2000. Consequently, Nord Pool is the oldest electricity market in Europe where a market splitting mechanism is implemented.

Elspot (Nord Pool's spot electricity market) calculates day-ahead prices for every hour and for each bidding area by establishing a balance between supply and demand bids. It also takes into account ATC (available transmission capacities) between the bidding areas. The congestion of interconnections between bidding areas creates the market splitting, with the electricity spot prices diverging. Bidding areas with lower prices export electricity to areas with higher prices through these limited capacity interconnections [56]. If the ATC is large enough to accommodate the exported electricity flows (no congestion), then the price is the same in both bidding areas. Therefore, this mechanism is supported on the calculation of the ATC, which is made by each TSO taking into account the safety and reliability of the electrical system. Depending on loop flows and technical constraints imposed by TSOs, import and export ATC can have different values [57].

Denmark is divided into two bidding areas, interconnected through the HV electricity grid. Moreover, Denmark is also interconnected with Norway and Sweden in the north and Germany in the south. The interconnection capacity between the two Danish bidding areas is $600 \mathrm{MW}$ through a HV Direct Current cable. The interconnection capacities and bidding areas are shown in Fig. 3. Interconnections capacity between the considered areas are higher than the current EU recommended level of $10 \%$ of the peak demand of the smaller interconnected market [59]. Denmark has already surpassed this value reaching $23.8 \%$ between West and East Denmark (DK1-DK2), 15.9\% between West Denmark (DK1) and Sweden bidding area 3 (SE3), 64.5\% between East Denmark (DK2) and Swedish bidding area 4 (SE4), 23.8\% between East Denmark (DK2) and Germany and 38.3\% between West Denmark (DK1) and Germany, all of the peak demand observed in the period considered in this study.

\section{Data and methods}

Following the methodology described in Ref. [36], expanded to a new multi-interconnected electricity market, market splitting behaviour was modelled through logit and non-parametric models estimating the probabilities of its occurrence. In the estimated models the introduction of electricity flows and market splitting binary variables of surrounding interconnected bidding areas introduce an additional complexity in relation to the models used in Ref. [36], where the interconnection between Spain and France was not considered. In the estimated models the probability response for market splitting of day-ahead spot electricity prices is expressed as a function of wind power generation shares, electricity demands, five interconnection electricity flow shares and five market splitting binary variables. These variables correspond to the two Danish bidding areas, the Swedish bidding areas 3 and 4, the Norwich bidding area 2 and Germany, which are all adjacent.

By imposing a parameter approach, logit models provide a general indication of the effects of each variable ("ceteris paribus"), which might change with others. Additionally, logit models present known specification restrictions, such as: 


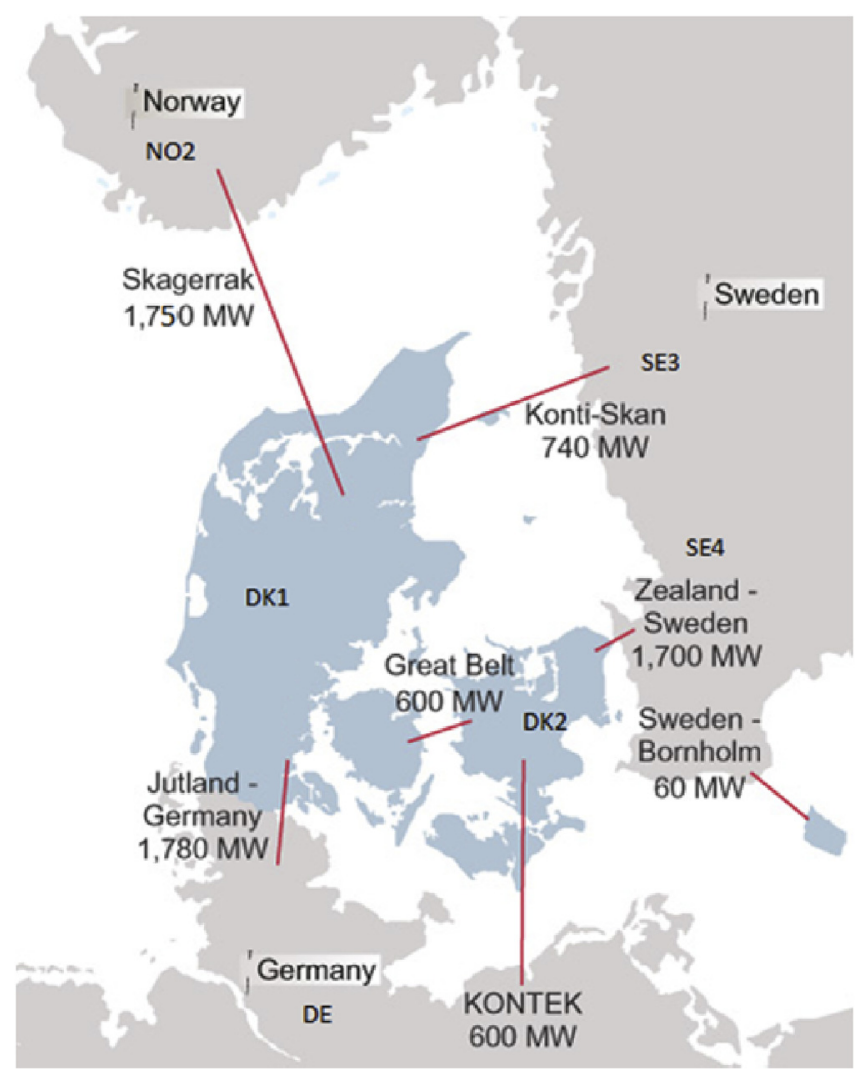

Fig. 3. Denmark's bidding areas and interconnections [58].

- The "Neglected Heterogeneity" specification issue, where the coefficient estimates may cause an underestimation of the effects - extraction of explanatory variables relative effects can still be of use $[60,61]$;

- Heteroskedasticity of the error term - A correction can be used according with $[62,63]$.

Yet, logit models can provide some preliminary indications about the model behaviour. The non-parametric models, herein used, do not require parametric assumptions for the underlying data generation process, therefore the logit specification limitations are avoided. One of the main set-backs of non-parametric modelling is the required computer processing resources when using large datasets, as it is inhere the case where the model estimation took several days to run, even with parallel processing. Furthermore, the "Curse of Dimensionality", related with the number of continuous explanatory variables, might deteriorate the convergence rate of the kernel functions, nevertheless models remain consistent [64]. In our models the sample size overcomes this issue.

In the following Section 3.1 the data used in this study is presented, followed by the logit model specification in Section 3.2 and the non-parametric model specification in Section 3.3.

\subsection{Data}

Day-ahead spot electricity prices in $€ / M W h$, interconnection flows in MWh, Demand in MWh and Wind Power Generation in MWh, for each hour from the 2nd of January 2012 until the 31st of December 2014, were extracted from the Nord Pool Spot ftp server [45] and from EPEX Spot web site [65], for both Danish and adjacent bidding areas. This consists in a sample of $26,281 \mathrm{~h}$.

The demand of the Danish electricity market has a peak of
6.5 GWh, which is comparably small with the demand in Norway, with a peak of $24.2 \mathrm{GWh}$, and the demand in Sweden, with a peak of 26.6 GWh. However, when these electricity markets are divided into bidding areas, the only bidding area that stands out is the Swedish bidding area 3 with a demand peak of 17.5 GWh [45]. Germany with its 77.2 GWh of peak demand is by large the biggest connected electricity market [66].

By using a rolling window procedure for the number of market splitting hours in a month, a trend is established and can be plotted. Therefore, a price convergence can be observed in the case of reducing number of market splitting hours in a rolling month. Between West and East Denmark (DK1-DK2), the number of market splitting hours in a moving month remains low, with an exception during a small period in the end of 2013 and 2014 (Fig. 4). Furthermore, it seems that there is a higher integration level between both Danish bidding areas and between East Denmark (DK2) and Sweden bidding area 4 . In this period, market splitting between both Danish biding areas occurred in 23.3\% of the total $26,281 \mathrm{~h}$ considered in our sample. Likewise, market splitting occurred $60.4 \%$ between West Denmark (DK1) and Norway bidding area 2, 44.3\% between West Denmark (DK1) and Sweden bidding area 3, 24.3\% between East Denmark (DK2) and Sweden bidding area $4,64.8 \%$ between West Denmark (DK1) and Germany and $69.5 \%$ between East Denmark (DK2) and Germany, of the total sample.

Fig. 5 plots the spot electricity price differences between West Denmark (DK1) and East Denmark (DK2), showing that multiple market splitting hours occurred in the period herein considered. It is also observed that there are more data points below zero, which means that prices in East Denmark (DK2) are frequently higher than the ones in West Denmark (DK1).

In Fig. 6 the interconnection cross-border flows between Denmark and the Nord Pool adjacent areas are plotted. The interconnection transfer flows plot between both Danish bidding areas reveals that, most of the time the electricity flow direction is from West to East Denmark. This is consistent with the lower prices observed in West Denmark (Fig. 5). The interconnection transfer flows between East Denmark and Sweden have a slight tendency to be predominantly in the direction from Sweden to East Denmark, indicating lower prices in Sweden bidding area 4. No significant asymmetries are observed in the remaining interconnection flow plots, which indicate that there is no evident preferred direction for the cross-border flows.

In Appendix A, Table 5 with the summary statistics is presented for the considered time series. All price time-series have nonnormal distributions, as determined by the rejection of the null for the Jarque-Bera normal distribution test.

\subsection{Logit model estimation}

Following the logit specification in Ref. [36], the estimated market splitting probability model expresses the probability of occurring different prices, thus interconnection congestion, between both Danish bidding areas.

The model specification used is:

$$
\begin{aligned}
& P(\text { Split }=1 \mid X)=P\left(\text { Split }^{*}>0 \mid X\right)=P(X \beta+e>0 \mid X), \\
& P(e>-X \beta \mid X)=1-P(e \leq-X \beta \mid X)=1-\Lambda(-X \beta)=\Lambda(X \beta),
\end{aligned}
$$

where $\Lambda(X \beta)=\frac{\exp (X \beta)}{1+\exp (X \beta)}$.

Split is the binary dependent variable, $X$ a matrix of explanatory variables and $e$ is the independently distributed error term 
Number of market splitting hours in a moving month
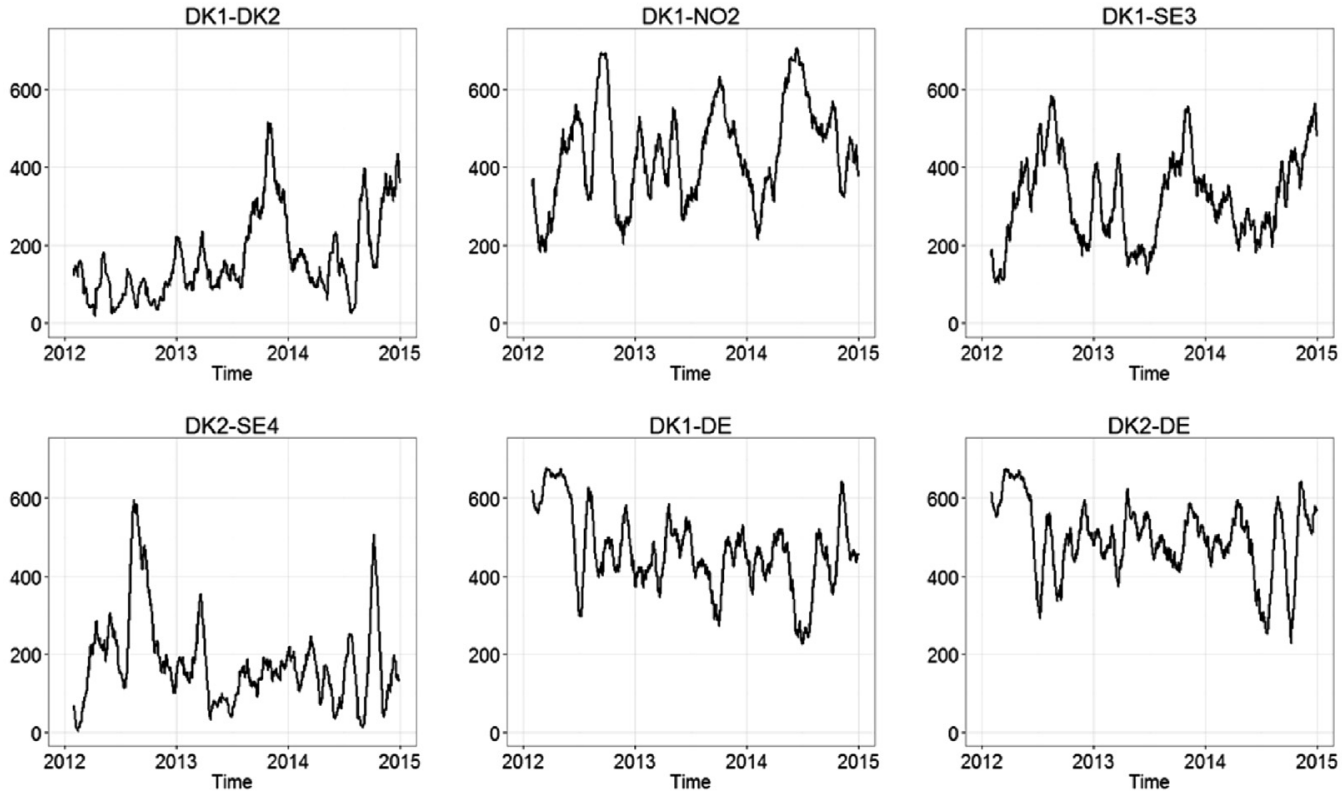

Fig. 4. Market splitting evolution.

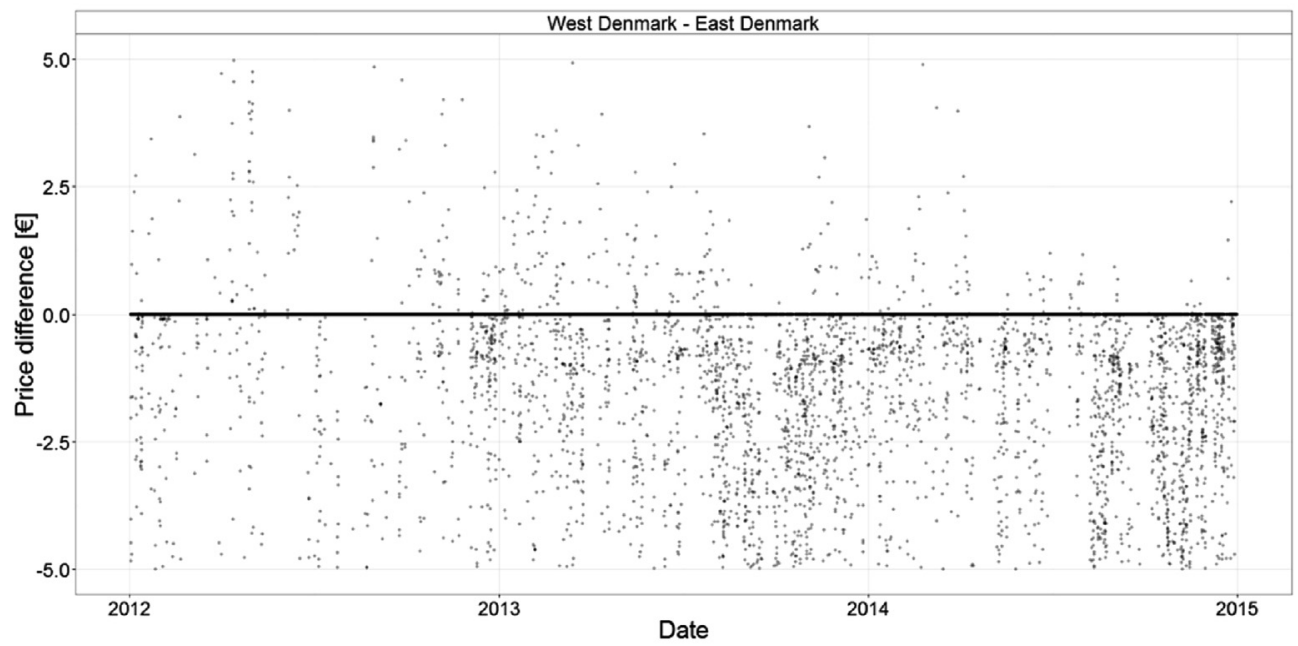

Fig. 5. Spot electricity price differences between Danish bidding areas.

independent from $X$ and following the standard logistic distribution. The Split ${ }^{*}$ latent variable is then expressed as follows:

$$
\begin{aligned}
\text { Split }^{*}= & \beta_{0}+\beta_{1} \cdot W_{D K 1} / D_{D K 1}+\beta_{2} \cdot W_{D K 2} / D_{D K 2}+\beta_{3} \cdot D_{D K 1} \\
& +\beta_{4} \cdot D_{D K 2}+\beta_{5} \cdot D_{N O 2}+\beta_{6} \cdot D_{S E 3}+\beta_{7} \cdot D_{S E 4}+\beta_{8} \cdot D_{D E} \\
& +\beta_{9} \cdot \text { Flow }_{D K 1-N O 2}+\beta_{10} \cdot \text { Flow }_{D K 1-S E 3} \\
& +\beta_{11} \cdot \text { Flow }_{D K 2-S E 4}+\beta_{12} \cdot \text { Flow }_{D K 1-D E} \\
& +\beta_{13} \cdot \text { Flow }_{D K 2-D E}+\beta_{14} \cdot \text { Split }_{D K 1-N O 2} \\
& +\beta_{15} \cdot \text { Split }_{D K 1-S E 3}+\beta_{16} \cdot \text { Split }_{D K 2-S E 4}+\beta_{17} \cdot \text { Split }_{D K 1-D E} \\
& +\beta_{18} \cdot \text { Split }_{D K 2-D E}+e,
\end{aligned}
$$

where $W_{D K 1}$ and $W_{D K 2}$ are the hourly wind power generation in West and East Denmark, respectively; $D_{D K 1}, D_{D K 2}, D_{N O 2}, D_{S E 3}, D_{S E 4}$ and $D_{D E}$ are the hourly electricity demand in West Denmark, East Denmark, Norway bidding area 2, Sweden bidding area 3, Sweden bidding area 4 and Germany, respectively; Flow DK1-NO2, Flow $_{D K 1-S E 3 \text {, }}$ Flow $_{D K 2-S E 4}$, Flow ${ }_{D K 1-D E}$ and Flow $w_{D K 2-D E}$ are the hourly interconnection cross-border flows between West Denmark - Norway bidding area 2, West Denmark - Sweden bidding area 3, East Denmark - Sweden bidding area 4, West Denmark - Germany and East Denmark - Germany, respectively; and Split ${ }_{D K 1-N O 2 \text {, }}$ Split $_{D K 1-S E 3}$, Split $_{D K 2-S E 4}$, Split $_{D K 1-D E}$ and Split $t_{D K 2-D E}$ are the hourly binary variables representing market splitting between West Denmark - Norway bidding area 2, West Denmark - Sweden bidding area 3 East Denmark - Sweden bidding area 4, West Denmark - Germany and East Denmark - Germany electricity markets, respectively. 

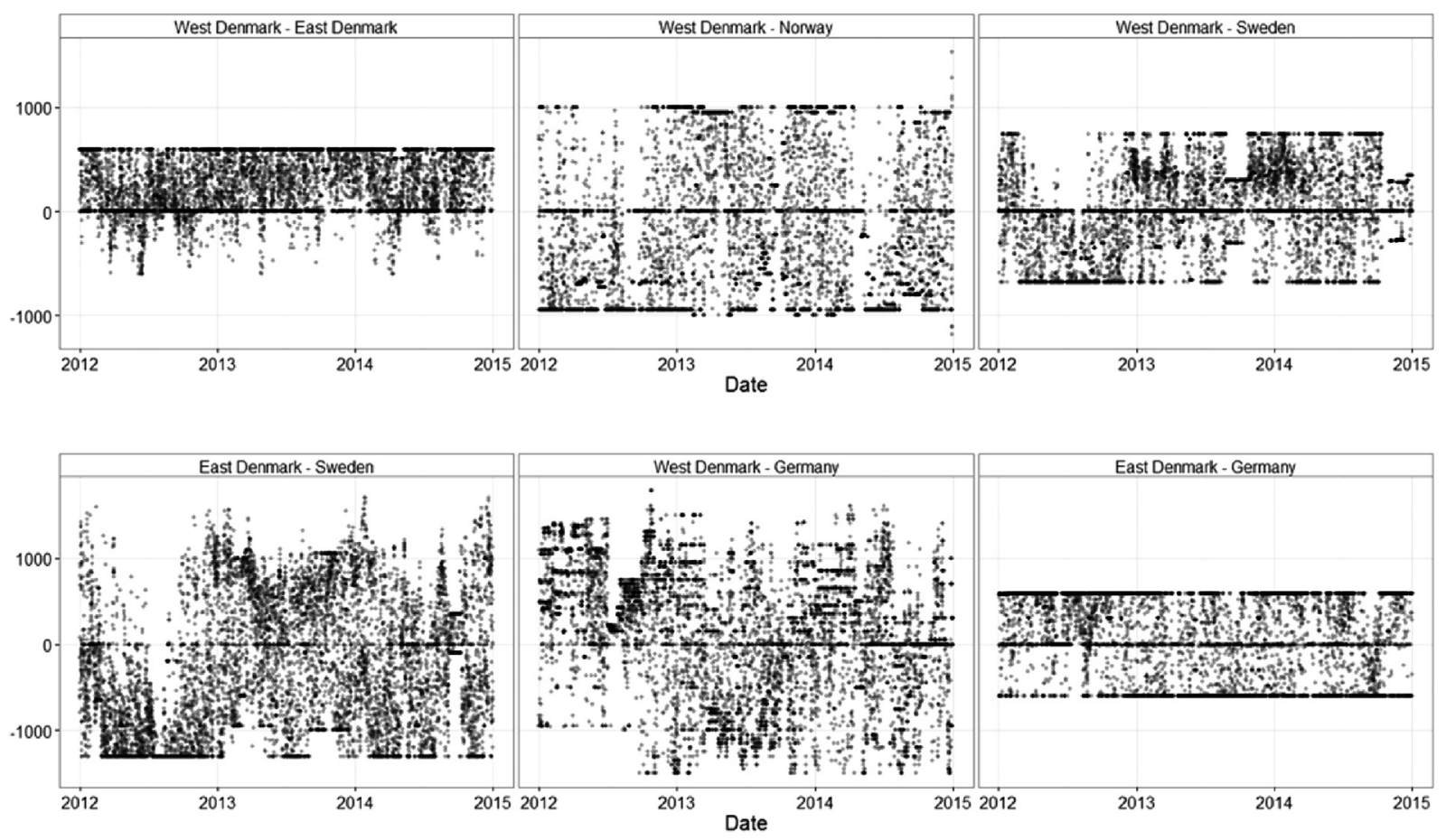

Fig. 6. Interconnection cross-border flows with Danish adjacent bidding areas.

\subsection{Non-parametric model estimation}

As described in Ref. [36] the underlying data generation process is not required for non-parametric models, avoiding specification issues that can question parametric models [67]. Model estimation is performed through kernel methods with the information provided by the data. An introduction to non-parametric modelling can be found in Refs. [64,68].

Therefore, by using the "npRmpi" package for non-parametric kernel estimation [68] developed in $\mathrm{R}$ [69], the models inhere used overcome the logit specification issues. With the required information from the data, model estimation is done through kernel methods and the associated bandwidth [70]. Parallel processing was used due to the large datasets analysed in this study.

The market splitting probability is estimated by the conditional PDF (probability density function) expressing the probability of occurring different prices between both Danish bidding areas, conditional on the considered explanatory variables. The conditional PDF is then:

$\widehat{f}\left(y^{d} \mid x^{d}, x^{c}\right)=\frac{\widehat{f}\left(y^{d}, x^{d}, x^{c}\right)}{\widehat{f}\left(x^{d}, x^{c}\right)}$

where $\widehat{f}\left(y^{d}, x^{d}, x^{c}\right)$ is the joint PDF, $\widehat{f}\left(x^{d}, x^{c}\right)$ the marginal PDF, $y^{d}$ the discrete dependent variable, $x^{d}$ the discrete explanatory variables and $x^{c}$ the continuous explanatory variables. As described in Section 3.2 the variables used are: $y^{d}$ is the binary variable Split expressing market splitting between both Danish bidding areas; $x^{d}$ are the binary variables representing market splitting Split ${ }_{D K 1}$ ${ }_{N O 2}$, Split DK1-SE3, Split $_{D K 2-S E 4}$, Split $_{D K 1-D E}$ and Split $t_{D K 2-D E}$; and $x^{c}$ are the wind power generation variables $W_{D K 1}$ and $W_{D K 2}$, the electricity demand variables $D_{D K 1}, D_{D K 2}, D_{N O 2}, D_{S E 3}, D_{S E 4}$ and $D_{D E}$, and the interconnection cross-border flow variables Flow DK1-NO2, Flow DK1-SE3, Flow $_{D K 2-S E 4}$, Flow ${ }_{D K 1-D E}$ and Flow ${ }_{D K 2-D E}$.

The joint PDF can then be estimated by:

$\widehat{f}\left(y^{d}, x^{d}, x^{c}\right)=\frac{1}{n} \sum_{i=1}^{n} L_{\lambda_{y}, Y_{i}^{d}, y^{d}} \cdot L_{\lambda_{x}, X_{i}^{d}, x^{d}} \cdot W_{h_{x}, X_{i}^{c}, x^{c}}$

and the marginal PDF by:

$\widehat{f}\left(x^{d}, x^{c}\right)=\frac{1}{n} \sum_{i=1}^{n} L_{\lambda_{x}, X_{i}^{d}, x^{d}} \cdot W_{h_{x}, X_{i}^{c}, x^{c}}$

where $L(\cdot)$ and $W(\cdot)$ are product kernel functions for discrete and continuous variables, respectively. For discrete variables:

$L_{\lambda_{x}, X_{i}^{d}, x^{d}}=\prod_{s=1}^{r_{x, d}} l\left(X_{i, s}^{d}, x_{s}^{d}, \lambda_{x, s}\right)$

$l\left(X_{i, s}^{d}, x_{s}^{d}, \lambda_{x, s}\right)=\left\{\begin{array}{cl}1-\lambda_{x, s}, & \text { if } X_{i, s}^{d}=x_{s}^{d} \\ \frac{\lambda_{x, s}}{c_{s}-1}, & \text { otherwise }\end{array}\right.$,

where $l(\cdot)$ is the discrete univariate kernel function proposed by Ref. [71], $r_{x, d}$ the number of discrete explanatory variables, $c_{s}$ the number of outcomes in $x_{s}$ and $\lambda_{x, s}$ the bandwidth, with $\lambda_{x, s} \varepsilon\left[0,\left(c_{s}-1\right) / c_{s}\right]$. For continuous variables:

$W_{h_{x}, X_{i}^{c}, x^{c}}=\prod_{s=1}^{r_{x, c}} \frac{1}{h_{x, S}} w\left(\frac{X_{i, s}^{c}-x_{s}^{c}}{h_{x, S}}\right)$ 
$w\left(\frac{X_{i, s}^{c}-x_{s}^{c}}{h_{x, S}}\right)=\frac{e^{\left(-\left(\frac{x_{i}-x_{s}^{c}}{h_{x, s}}\right)^{2} / 2\right)}}{\sqrt{2 \pi}}$,

where $w(\cdot)$ is the continuous univariate Second-order Gaussian kernel function, $r_{x, c}$ the number of continuous explanatory variables and $h_{x, s}$ the bandwidth of variable $s$.

Bandwidth selection is a fundamental part of non-parametric estimation, therefore two methods were attempted: the "rule of thumb" and "likelihood cross-validation".

The "rule of band of thumb" bandwidth is given by:

$h=1.06 \cdot \sigma \cdot n^{-1 /(2 P+l)}$,

where $\sigma$ is the $\min (\sigma$, interquartile range/1.349), $n$ the number of observations, $P$ the order of the kernel and $l$ the number of continuous variables.

The "likelihood cross-validation" method selects the bandwidth ( $h$ ) by maximizing the following log likelihood function:

$\mathscr{L}=\sum_{i=1}^{n} \log \left[\frac{1}{(n-1) h} \sum_{j=1, j \neq i}^{n} K\left(\frac{X_{j}-x}{h}\right)\right]$

Finally, the most adequate method was then selected according to model performance [72].

By using the same explanatory variables as in the logit model, the non-parametric models were estimated with bandwidths calculated with both selection methods and considering the same data set.

\section{Results}

In the following Sections 4.1 and 4.2 results and performance are presented for both logit and non-parametric models.

\subsection{Logit model results}

All coefficients are statistically significant $(\mathrm{p}<0.01)$ in the estimated model, with the exception of demand Norway area 2 and demand Sweden area 3, both significant at least to $10 \%$, and the binary variables representing market splitting between West Denmark (DK1) - Sweden area 3 and East Denmark (DK2) Sweden area 4 (Table 1) are not significant.

An attempt to correct the heteroskedasticity of the error term (Breusch-Pagan test in Table 2) was performed [36], but with little or no improvement on model performance. For the estimated model an accuracy of 0.9107 and a McFadden pseudo R-square of 0.544 were found (Table 2). The coeficients for the introduced correction variables in the skedastic function are significant $(\mathrm{p}<0.01)$ with the exception of the cross-border flow share from West Denmark to Norway area 2 (significant to $10 \%$ ) and the crossborder flow share from East Denmark to Germany (Table 1). Moreover, notwithstanding the "Neglected Heterogeneity" specification issue of the logit models, extraction of the relative effects can be made $[60,61]$.

\subsection{Non-parametric model results}

In Table 3 confusion matrices for both estimated models are presented and in Table 4 the results for the bandwidth calculation are shown. Non-parametric models are revealed to have improved performance, in addition to the absence of the specification issues of the logit models. An accuracy of 0.9965 is obtained with the bandwidth selected by likelihood cross-validation, the highest amongst all estimated models.

In Fig. 7 the observed and the fitted number of market splitting hours in a rolling month are shown in the sample period, for the measured data, for the heteroskedasticity corrected logit model and for the likelihood cross-validation non-parametric model. As demonstrated, the performance of the non-parametric model is clearly better than the one obtained by the logit model.

\section{Discussion}

For clarification purposes, when market splitting probability is referred to, it means the probability of market splitting occurrence between West and East Denmark (the Danish splitting: DK1-DK2). No other market splitting probability is estimated in this study. Considering the results of the logit models and their marginal effects (Table 1), together with the 3D plots of the non-parametric models, it is possible to unveil the complex behaviour of the Danish electricity market splitting as observed in Figs. 8 and 9. Given that the "likelihood cross-validation" non-parametric model has the highest performance amongst all estimated models, the following interpretations are based on this model.

Fig. 8 shows (from top to bottom and left to right) the behaviour of market splitting probability response as a function of wind power generation in West and East Denmark: a) given market splitting occurrence between Denmark and all adjacent bidding areas (Denmark isolated); b) given market splitting occurrence between Denmark and all adjacent bidding areas with the exception of West Denmark (DK1) to Norway bidding area 2; c) given market splitting occurrence between Denmark and all adjacent bidding areas with the exception of West Denmark (DK1) to Sweden bidding area 3; d) given market splitting occurrence between Denmark and all adjacent bidding areas with the exception of East Denmark (DK2) to Sweden bidding area 4; e) given market splitting occurrence between Denmark and all adjacent bidding areas with the exception of West Denmark (DK1) to Germany; and f) given market splitting occurrence between Denmark and all adjacent bidding areas with the exception of East Denmark (DK2) to Germany. Fig. 9 shows (from top to bottom and left to right) the behaviour of market splitting probability response as a function of wind power generation in West and East Denmark: a) given no market splitting occurrence between Denmark and all adjacent bidding areas (absence of congestions, therefore it is expected a null probability of market splitting); b) given no market splitting occurrence between Denmark and all adjacent bidding areas with the exception of West Denmark (DK1) to Norway bidding area 2; c) given no market splitting occurrence between Denmark and all adjacent bidding areas with the exception of West Denmark (DK1) to Sweden bidding area 3 ; d) given no market splitting occurrence between Denmark and all adjacent bidding areas with the exception of East Denmark (DK2) to Sweden bidding area 4; e) given no market splitting occurrence between Denmark and all adjacent bidding areas with the exception of West Denmark (DK1) to Germany; and f) given no market splitting occurrence between Denmark and all adjacent bidding areas with the exception of East Denmark (DK2) to Germany.

The results obtained from the models express that, generally speaking, market splitting probability between both Danish bidding areas is sensitive to the wind power generation share in Denmark, nevertheless with distinct behaviour according to the congestion of interconnections with other bidding areas. The simplistic interpretation that can be done with the obtained logit marginal effects does not suffice. For example, the decreasing probability with increasing wind power in East Denmark can only be related with the situation when Denmark is isolated, with the 
Table 1

Market splitting logit model.

Dependent variable: Market Split

Data: 2nd January 2012 to 31st December 2014

Coefficients (binomial model with logit link):

\begin{tabular}{|c|c|c|c|c|}
\hline \multirow[b]{2}{*}{ c } & \multicolumn{2}{|c|}{ No het. correction } & \multicolumn{2}{|c|}{ Het. correction } \\
\hline & -8.3970 & $* * *$ & -11.0900 & $* * *$ \\
\hline Wind share West Denmark & 1.5030 & $* * *$ & 1.7940 & $* * *$ \\
\hline Wind share East Denmark & -3.0440 & $* * *$ & -4.5820 & $* * *$ \\
\hline Demand West Denmark & 0.0011 & $* * *$ & 0.0016 & $* * *$ \\
\hline Demand East Denmark & 0.0013 & $* * *$ & 0.0021 & $* * *$ \\
\hline Demand Norway area 2 & 0.0002 & $*$ & 0.0004 & $* *$ \\
\hline Demand Sweden area 3 & -0.0001 & $* *$ & -0.0001 & $*$ \\
\hline Demand Sweden area 4 & -0.0010 & $* * *$ & -0.0017 & $* * *$ \\
\hline Demand Germany & 0.0000 & $* * *$ & 0.0000 & $* * *$ \\
\hline Cross-border flow share West Denmark to Norway area 2 & -2.6170 & $* * *$ & -3.0360 & $* * *$ \\
\hline Cross-border flow share West Denmark to Sweden area 3 & 3.7040 & $* * *$ & 4.8440 & $* * *$ \\
\hline Cross-border flow share East Denmark to Sweden area 4 & 2.6360 & $* * *$ & 4.3300 & $* * *$ \\
\hline Cross-border flow share East Denmark to Germany & -1.2560 & $* * *$ & -1.1420 & $* * *$ \\
\hline Cross-border flow share West Denmark to Germany & 2.4670 & $* * *$ & 4.2090 & $* * *$ \\
\hline Market splitting West Denmark to Norway area 2 & -0.6398 & $* * *$ & -0.7943 & $* * *$ \\
\hline Market splitting West Denmark to Sweden area 3 & -16.8500 & & -52.9300 & \\
\hline Market splitting East Denmark to Sweden area 4 & 22.1200 & & 59.1200 & \\
\hline Market splitting West Denmark to Germany & 0.2171 & $* * *$ & 0.2820 & $* * *$ \\
\hline Market splitting East Denmark to Germany & 1.8210 & $* * *$ & 2.3020 & *** \\
\hline \multicolumn{5}{|l|}{ Latent scale model coefficients (with log link): } \\
\hline Wind share West Denmark & & & -0.3352 & $* * *$ \\
\hline Wind share East Denmark & & & 0.9903 & $* * *$ \\
\hline Cross-border flow share West Denmark to Norway area 2 & & & -0.1555 & * \\
\hline Cross-border flow share West Denmark to Sweden area 3 & & & -0.7277 & $* * *$ \\
\hline Cross-border flow share East Denmark to Sweden area 4 & & & -0.7724 & $* * *$ \\
\hline Cross-border flow share East Denmark to Germany & & & -0.0223 & \\
\hline Cross-border flow share West Denmark to Germany & & & -0.6888 & $* * *$ \\
\hline
\end{tabular}

*** Significant at $1 \%$ level, ${ }^{* *}$ Significant at $5 \%$ level, ${ }^{*}$ Significant at $10 \%$ level.

exception of the interconnection West Denmark (DK1) - Sweden bidding area 3 (Fig. 8 bottom left), and the situation when Denmark is not isolated, with the exception of West Denmark (DK1) - Germany (Fig. 9 center right). The former can be associated with wind power from West Denmark (DK1) being able to be exported to Sweden and not to East Denmark (DK2), with the sudden drop of the West Danish electricity price (DK1) caused by the high wind power generation share originating a detour of the electricity flow into Sweden bidding area 3, and releasing some cross-border

Table 2

Market splitting logit model performance.

\begin{tabular}{cc}
\hline No het. Correction & Het. Correction \\
\hline McFadden pseudo R-squared: & \\
$0.6046877(d f=19)$ & $0.6339591(d f=26)$
\end{tabular}

\begin{tabular}{|c|c|c|c|c|c|}
\hline \multicolumn{6}{|c|}{$\begin{array}{l}\text { Studentized Breusch-Pagan test } \\
\text { data: ms.logit } \\
\text { BP }=6837.368, d f=18, p \text {-value }<2.2 e-16\end{array}$} \\
\hline \multicolumn{6}{|c|}{ In-sample performance } \\
\hline \multicolumn{6}{|c|}{ Data: 2nd of January 2012 to 31st of December 2014} \\
\hline \multirow{2}{*}{\multicolumn{2}{|c|}{ Confusion Matrices }} & \multicolumn{2}{|c|}{ Predicted } & \multicolumn{2}{|c|}{ Predicted } \\
\hline & & 0 & 1 & 0 & 1 \\
\hline \multirow[t]{2}{*}{ Observed: } & 0 & 19396 & 703 & 19570 & 529 \\
\hline & 1 & 988 & 5047 & 1144 & 4891 \\
\hline Accuracy (CCR) & & 0.93 & & 0.93 & \\
\hline Sensitivity (TPR) & & 0.83 & & 0.81 & \\
\hline Specificity (SPC) & & 0.96 & & 0.97 & \\
\hline
\end{tabular}

transmission capacity between West and East Denmark. The latter can be associated with increasing wind power in East Denmark (DK2) stopping incoming interconnection electricity flows from West Denmark (DK1), which can not flow into Germany. These findings expand on [33-36] and unveil a more complex behaviour of multiple interconnected electricity markets.

In the case that Denmark is isolated from the adjacent electricity markets (Fig. 8 top left), market splitting probability between West and East Denmark (DK1-DK2) increases when there is an increase of wind power generation share in both West and East Denmark.

Table 3

Market splitting non-parametric model performance.

Continuous Kernel Type: Second-Order Gaussian

No. Continuous Explanatory Vars.: 13

Unordered Categorical Kernel Type: Aitchison and Aitken

No. Unordered Categorical Explanatory Vars.: 5

No. Unordered Categorical Dependent Vars.: 1

In-sample performance

Data: $2^{\text {nd }}$ January 2012 to $31^{\text {st }}$ December 2014

"Rule-of-Thumb" "Cross-validation"

Confusion Matrices:

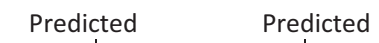

\begin{tabular}{lcc|cc|c} 
& & 0 & 1 & 0 & 1 \\
Observed: & 0 & 20081 & 18 & 20087 & 12 \\
\hline & 1 & 305 & 5737 & 80 & 5955 \\
& \multicolumn{3}{c}{ "Rule-of-Thumb" } & "Cross-validation" \\
Accuracy (CCR) & \multicolumn{3}{c}{0.9876} & 0.9965 \\
Sensitivity (TPR) & & 0.9495 & 0.9867 \\
Specificity (SPC) & & 0.9991 & 0.9994
\end{tabular}


Table 4

Market splitting non-parametric bandwidth.

\begin{tabular}{|c|c|c|}
\hline \multicolumn{3}{|c|}{$\begin{array}{l}\text { Dependent variable: Market Split DK1-DK2 } \\
\text { Bandwidth Type: Fixed } \\
\text { Conditional density data ( } 26146 \text { observations, } 19 \text { variable(s)) } \\
\text { (1 dependent variable(s), and } 18 \text { explanatory variable(s)) }\end{array}$} \\
\hline \multirow[t]{2}{*}{ Bandwidth Selection Method: } & Rule of Thumb & Likelihood cross-validation \\
\hline & Bandwidth: & Bandwidth: \\
\hline Market Split DK1-DK2 & 0 & 0.0005861131 \\
\hline Wind share DK2 & 0.09888924 & 0.08285425 \\
\hline Demand DK1 & 288.2946 & 306.5095 \\
\hline Demand DK2 & 191.5344 & 279.4728 \\
\hline Demand Norway 2 & 442.999 & 131.7723 \\
\hline Demand Sweden 3 & 1331.377 & 722.8817 \\
\hline Demand Sweden 4 & 399.4506 & 207.3693 \\
\hline Cross-border flow share DK1-DE & 0.1818036 & 0.1684009 \\
\hline Cross-border flow share DK2-DE & 0.2038545 & 0.1028271 \\
\hline Market split DK1-NO2 & 0 & $7.853852 \mathrm{e}-08$ \\
\hline Market split DK1-SE3 & 0 & $4.398261 \mathrm{e}-07$ \\
\hline Market split DK2-SE4 & 0 & 0.1336549 \\
\hline Market split DK1-DE & 0 & $4.344162 \mathrm{e}-10$ \\
\hline Market split DK2-DE & 0 & $1.369426 \mathrm{e}-06$ \\
\hline \multicolumn{3}{|c|}{ Continuous Kernel Type: Second-Order Gaussian } \\
\hline \multicolumn{3}{|l|}{ No. Continuous Explanatory Vars.: 13} \\
\hline \multicolumn{3}{|c|}{ Unordered Categorical Kernel Type: Aitchison and Aitken } \\
\hline \multicolumn{3}{|c|}{ No. Unordered Categorical Explanatory Vars.: 5} \\
\hline \multicolumn{3}{|c|}{ No. Unordered Categorical Dependent Vars.: 1} \\
\hline
\end{tabular}

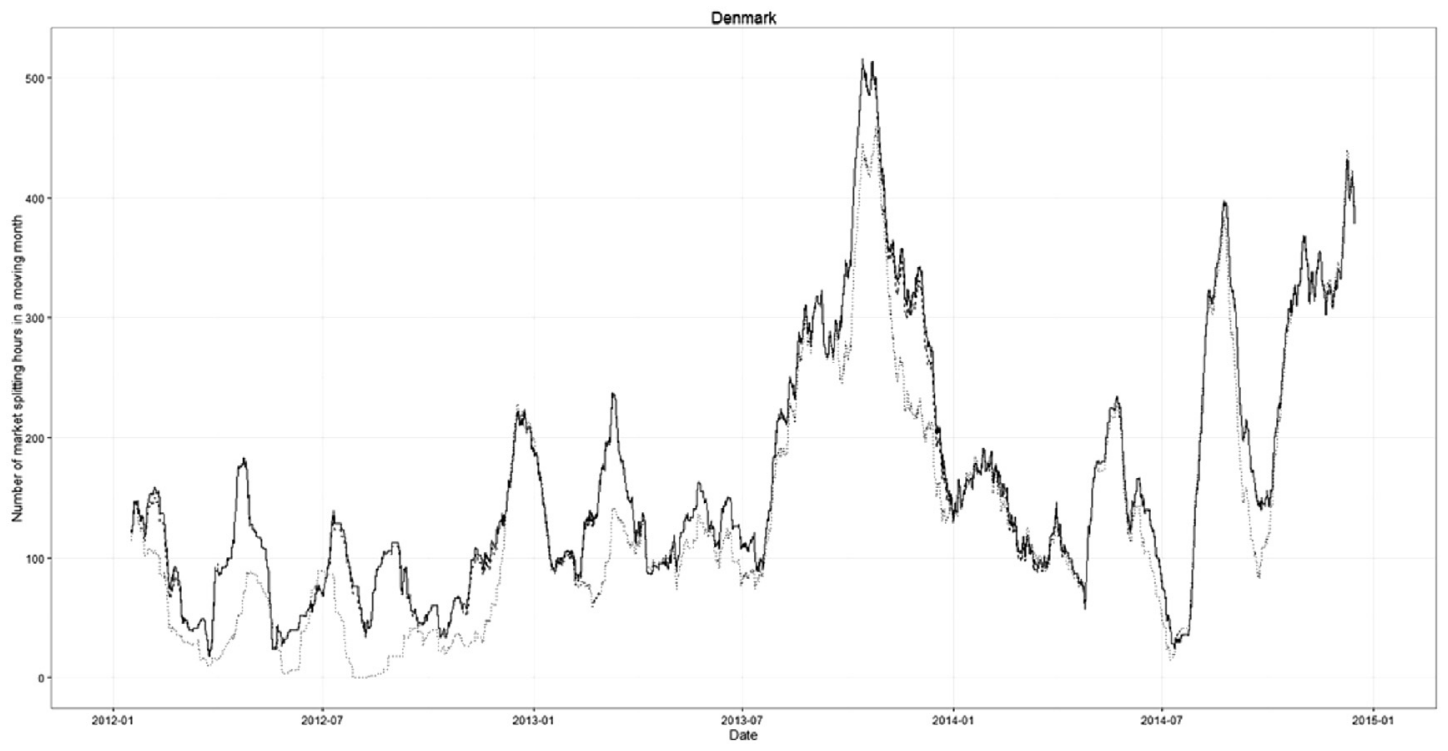

Fig. 7. Danish market splitting evolution (dotted - logit, dashed - non-parametric, solid - measured).

The shown behaviour can be explained by the asymmetric availability of low marginal cost electricity generated by the extensive existing wind power capacity in West Denmark (DK1), which is exported to East Denmark (DK2) with associated congestion of the Danish interconnection. The non-existence of market splitting between West Denmark (DK1) and Norway bidding area 2 (Fig. 8 center left) does not change significantly the market splitting response behaviour from the market configuration when Denmark is isolated (Fig. 8 top left). This demonstrates that the interconnection between West Denmark (DK1) and Norway bidding area 2 plays a limited role in the influence that wind power has on the behaviour of the Danish market splitting, perhaps due to the unnecessary import of electricity by Norway, which already has low cost electricity generation mainly from hydropower.

In the case that Denmark is not isolated from the adjacent electricity markets (Fig. 9 top left), the market splitting probability between West and East Denmark is null and the wind power generation share does not influence it. This behaviour can be explained by the ability of having all surplus electricity exported through the available cross-border interconnections and also not requiring external electricity infeed. Moreover, assuming Denmark not isolated from adjacent bidding areas with the exception of only 
Split with adjacent electricity markets

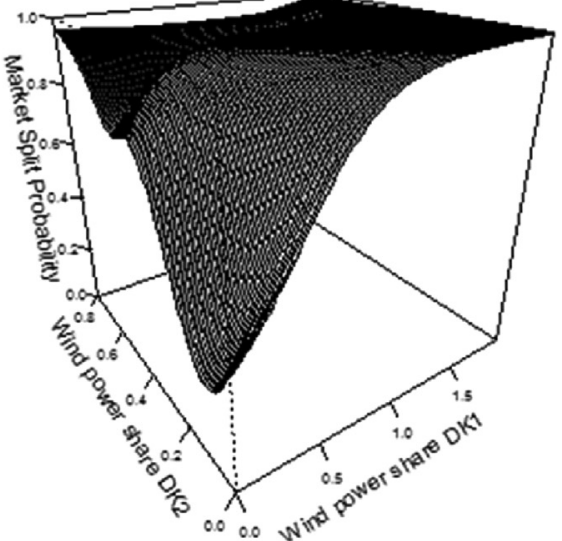

No split between DK1-NO2

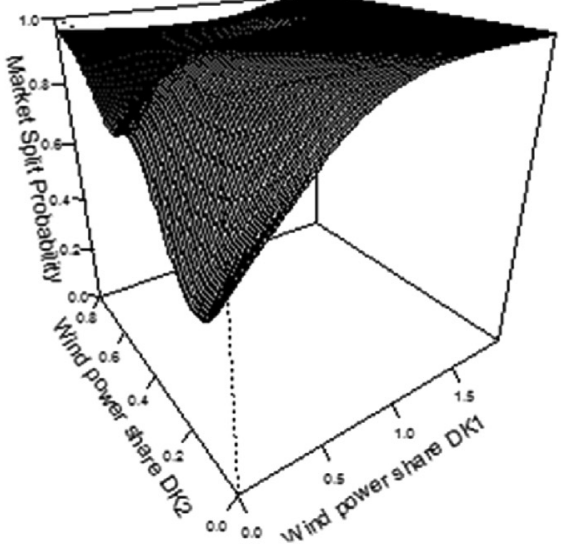

No split between DK1-SE3

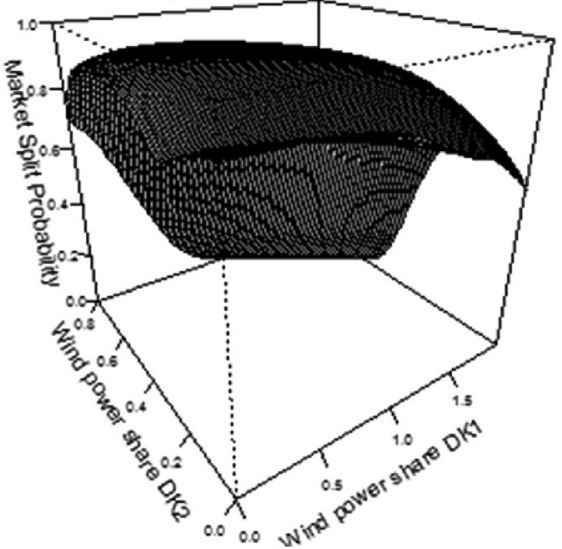

No split between DK2-SE4

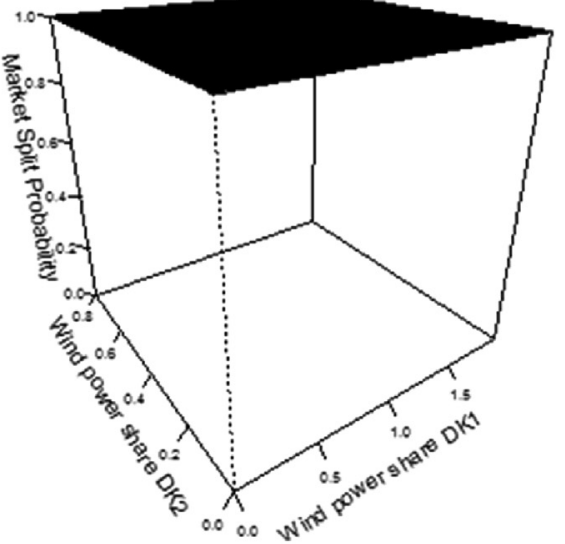

No split between DK1-DE

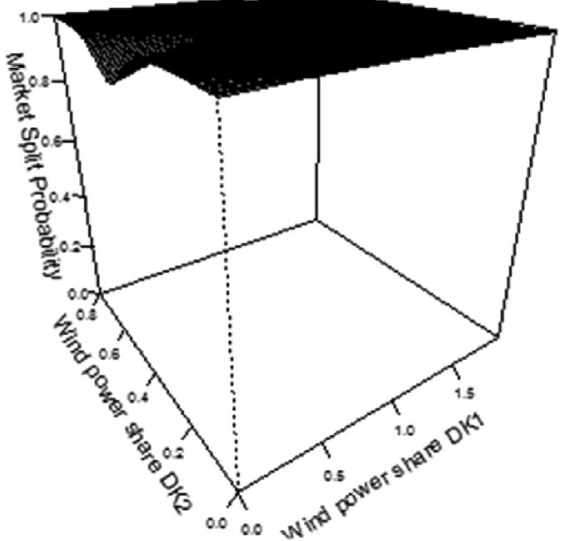

No split between DK2-DE

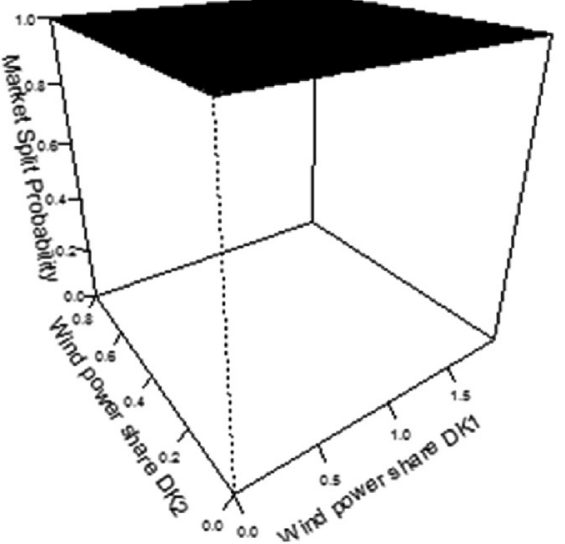

Fig. 8. Predicted probability response of market splitting between West and East Denmark to wind power generation share.

one of the interconnections with an adjacent bidding area, the probability response of the Danish splitting is also null. The available surplus of low cost electricity can always be exported through the available interconnections. As described above, with Denmark not isolated from adjacent bidding areas, with the exception of the interconnection West Denmark (DK1) - Germany (Fig. 9 center right), the probability response for the Danish splitting is high, even with low wind power generation, decreasing drastically with high wind power generation share in East Denmark (DK2). Thus, increasing wind power in East Denmark (DK2) may render unnecessary incoming interconnection electricity flows from West Denmark (DK1), which can not flow into Germany.

\section{Conclusions}

Two of the benefits of spot electricity markets integration are the optimization of RES-E generation and security of supply. In this context, the impact of increasing wind power generation on electricity spot market splitting in a multi-interconnected region is herein studied.

Being Denmark one of the best case studies due to the high level deployment of wind power and belonging to the oldest European integrated electricity market, the behaviour of market splitting between West and East Danish bidding areas was modelled through logit and non-parametric models, estimating the probabilities of its occurrence. Fundamentally, it is shown that wind power generation 
No split with adjacent electricity markets

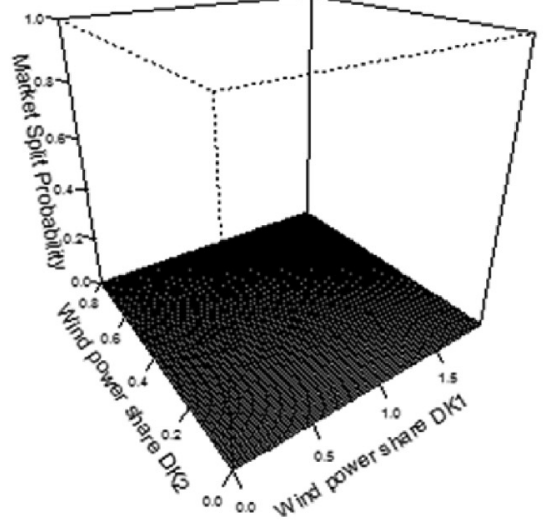

Split between DK1-NO2

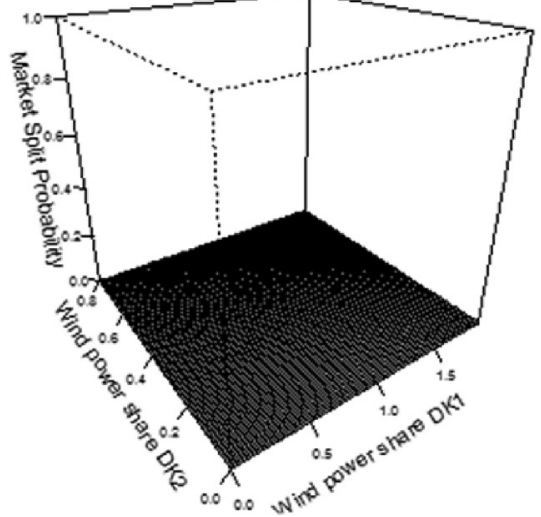

Split between DK1-SE3

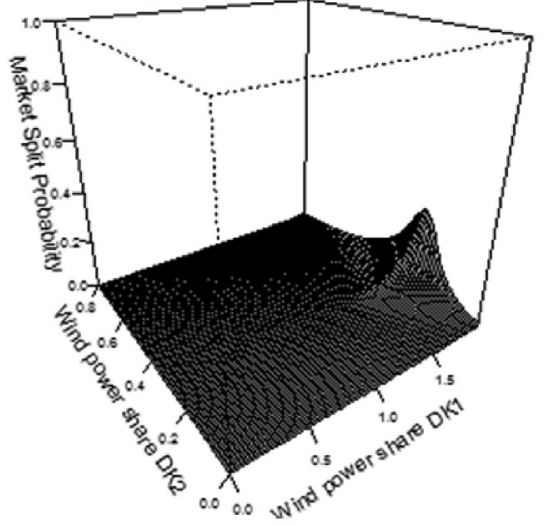

Split between DK2-SE4

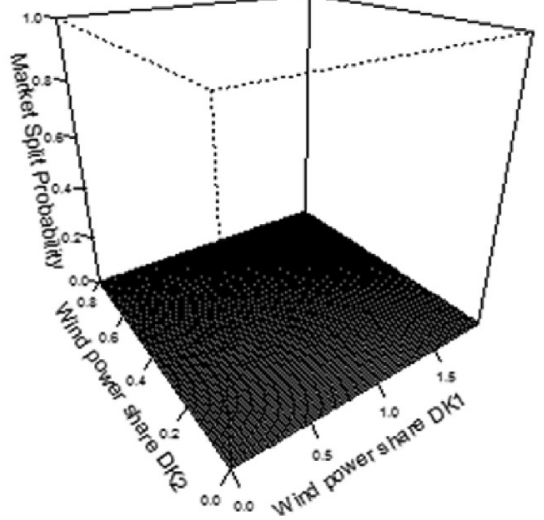

Split between DK1-DE

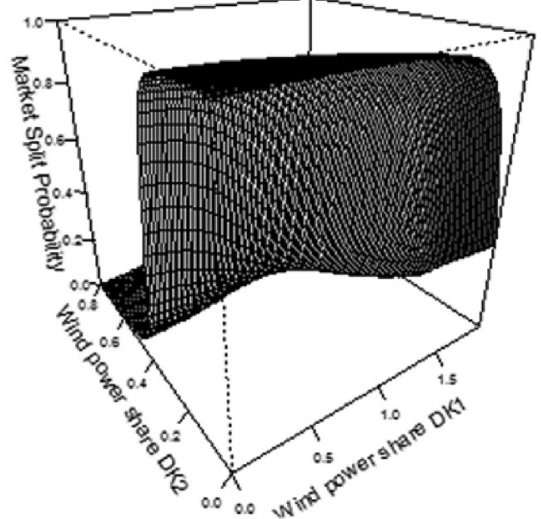

Split between DK2-DE

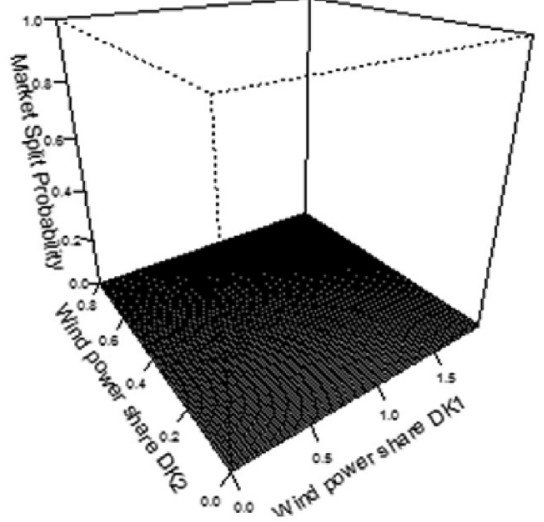

Fig. 9. Predicted probability response of market splitting between West and East Denmark to wind power generation share.

has a significant influence on market splitting behaviour. This behaviour, however, differs according to the congestion configuration of interconnections with adjacent bidding areas.

Considering the existing level of market splitting and the modelled behaviour we conclude that for the existing wind power generation, and furthermore, if there are intentions to further expand it, the existing interconnection between West and East Denmark is adequate, as the EU recommendation of $10 \%$ of the peak demand of the smaller interconnected market [59] is clearly surpassed, reaching a value of $16 \%$ in the considered data. Moreover, the occurrence of market splitting between West Denmark (DK1) and Germany should be avoided given the high probability of the Danish market splitting found to low West Denmark's (DK1) share of wind power (Fig. 9 center right). Therefore this cross-border interconnection should be reinforced in spite of the already $38,3 \%$ of the peak demand of the smaller interconnected market, which in this case is West Denmark's (DK1). Given that the cross-border interconnection between West Denmark (DK1) and Norway bidding area 2 does not have a meaningful impact on the probability response profile of the Danish market splitting, it is believed to have enough capacity and does not require reinforcing.

In order to decrease the market splitting probability level and the number of market splitting periods, resulting in increasing spot electricity price convergence and market integration, the requirements for interconnection capacity should be revised with the expansion of available wind power. Moreover, additional assessment should be made on the requirements for interconnection together with wind power expansion plans. Policies governing the coordination of both interconnection development and renewable incentives should be considered.

Further research should be focused in the analysis of other cross-border interconnections with Denmark, namely the new 
interconnections with the Netherlands, given the Price Coupling of Regions initiative. The complex dynamics existing in this electricity market setup might justify some of the obtained results, and a deeper analysis with additional electricity generation data could clarify some of these behaviours.

\section{Acknowledgements}

This work has been framed under the Energy for Sustainability Initiative of the University of Coimbra and also partially supported by the Portuguese Foundation for Science and Technology under project grant[s] UID/MULTI/00308/2013 .

We would also like to recognise the kind assistance provided by Nordpool Spot for making data available through their ftp, by Prof. Jeffrey Racine with software configuration for parallel processing of the non-parametric models and conference participants where extracts of our work were presented.

Table 5

Time series summary statistics.

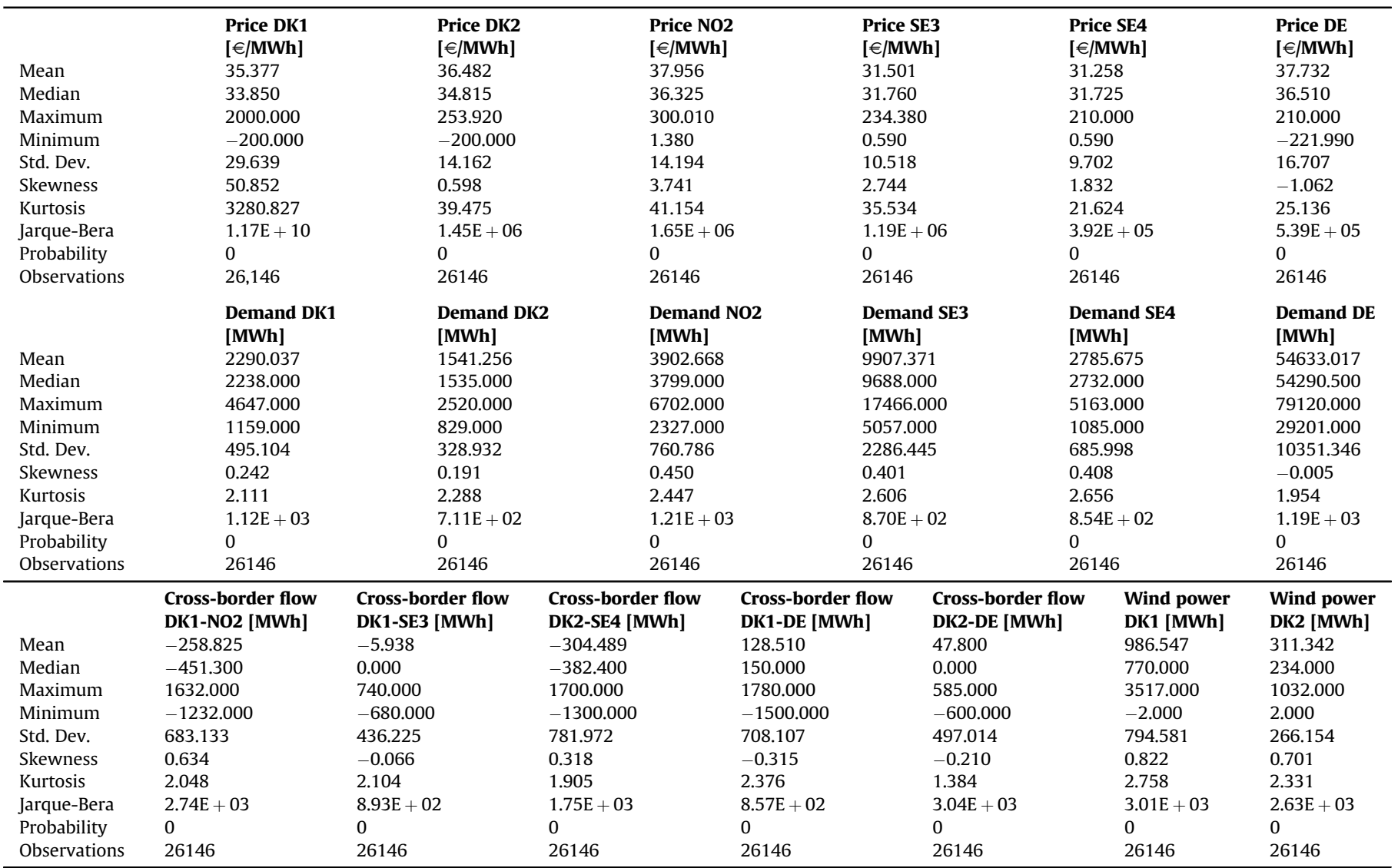

Notes: DK1 - West Denmark; DK2 - East Denmark; NO2 - Norway bidding area 2; SE3 - Sweden bidding area 3; SE4 - Sweden bidding area 4; DE - Germany.

\section{Appendix B}

Table 6

European electricity market integration references summary.

\begin{tabular}{|c|c|c|c|}
\hline References & Electricity markets analysed & Methods & Main results \\
\hline [14] & $\begin{array}{l}\text { Electricity price from } 3 \\
\text { January } 2000 \text { to } 25 \text { October 2003: } \\
\text { - West Denmark } \\
\text { - East Denmark } \\
\text { - Finland } \\
\text { - Mid Norway } \\
\text { - South Norway } \\
\text { - Sweden }\end{array}$ & $\begin{array}{l}\text { - Markov switching fractional cointegration } \\
\text { - regime switching multiplicative } \\
\text { seasonal ARFIMA model }\end{array}$ & $\begin{array}{l}\text { Cointegration exists only when interconnections between } \\
\text { West Denmark - Norway and East Denmark Sweden } \\
\text { bidding areas are not congested. }\end{array}$ \\
\hline
\end{tabular}


Table 6 (continued)

\begin{tabular}{|c|c|c|c|}
\hline References & Electricity markets analysed & Methods & Main results \\
\hline [15] & $\begin{array}{l}\text { Electricity price from } 2002 \text { to 2006: } \\
\text { - Austria } \\
\text { - France } \\
\text { - Germany } \\
\text { - Netherlands } \\
\text { - Spain } \\
\text { - UK } \\
\text { - Poland } \\
\text { - Czech Republic } \\
\text { - East Denmark } \\
\text { - West Denmark } \\
\text { - Sweden }\end{array}$ & $\begin{array}{l}\text { - Principal Component Analysis (PCA) } \\
\text { - Unit root tests } \\
\text { - Convergence test }\end{array}$ & $\begin{array}{l}\text { Convergence between both Danish bidding areas and } \\
\text { between East Denmark and Sweden had been achieved. }\end{array}$ \\
\hline [16] & $\begin{array}{l}\text { Electricity prices from } 1999 \text { to } 2006 \text { : } \\
\text { - Netherlands } \\
\text { - Germany } \\
\text { - Austria } \\
\text { - Scandinavia } \\
\text { - Spain } \\
\text { - France }\end{array}$ & $\begin{array}{l}\text { - Unit root tests } \\
\text { - Cointegration analysis }\end{array}$ & $\begin{array}{l}\text { The Nordic electricity markets were found not to be } \\
\text { integrated with Germany and the Netherlands. }\end{array}$ \\
\hline [17] & $\begin{array}{l}\text { Electricity prices from } 1998 \\
\text { to January 2012: } \\
\text { - Austria } \\
\text { - Belgium } \\
\text { - Czech Republic } \\
\text { - France } \\
\text { - Germany } \\
\text { - Greece } \\
\text { - Ireland } \\
\text { - Italy } \\
\text { - Poland } \\
\text { - Portugal } \\
\text { - Spain } \\
\text { - Switzerland } \\
\text { - the Netherlands } \\
\text { - the UK }\end{array}$ & $\begin{array}{l}\text { - Fractional cointegration analysis } \\
\text { - Multivariate GARCH model }\end{array}$ & $\begin{array}{l}\text { Nord Pool is found to be fractionally cointegrated } \\
\text { with the remaining analysed electricity markets and } \\
\text { that perfect integration had not been achieved. }\end{array}$ \\
\hline
\end{tabular}

\section{References}

[1] Henriot A, Lavoine O, Regairaz F, Hiroux-Marcy C, Gilmore J, Riesz J, et al. Market design for large scale integration of intermittent renewable energy sources. Report, CIGRE WG C5-11. 2013. p. 1-131.

[2] Ragwitz M, Steinhilber S, Breitschopf B, Isi F, Resch G, Panzer C, et al. REShaping: shaping an effective and efficient European renewable energy market. Rep Compil within Eur Res Proj RE-Shaping 2012:1-111.

[3] Carvalho MG, Bonifacio M, Dechamps P. Building a low carbon society. Energy 2011;36:1842-7. http://dx.doi.org/10.1016/j.energy.2010.09.030.

[4] Wiseman J, Edwards T, Luckins K. Post carbon pathways: a meta-analysis of 18 large-scale post carbon economy transition strategies. Environ Innov Soc Transitions 2013;8:76-93. http://dx.doi.org/10.1016/j.eist.2013.04.001.

[5] European Union. Roadmap for moving to a low-carbon economy in 2050. 2014. http://ec.europa.eu/clima/policies/roadmap/.

[6] European Union. Directive 2009/72/EC of the European Parliament and of the Council of 13 July 2009 concerning common rules for the internal market in electricity and repealing Directive 2003/54/EC. Off J Eur Union 2009:55-93. L 211.

[7] ERGEG. The electricity regional initiative: making progress towards a single european market. Electr Reg Initiat - Fact Sheet 2006:1-5.

[8] International Energy Agency. Denmark 2011 review. Report, Energy Policies IEA Ctries. 2011. p. 1-154.

[9] International Energy Agency. Wind annual report for 2013. Report. 2013. p. 80-5.

[10] De Vany AS, Walls WD. Cointegration analysis of spot electricity prices: insights on transmission efficiency in the western US. Energy Econ 1999;21: 435-48. http://dx.doi.org/10.1016/S0140-9883(99)00019-5.

[11] Park H, Mjelde JW, Bessler D a. Price dynamics among U.S. electricity spot markets. Energy Econ 2006;28:81-101. http://dx.doi.org/10.1016/ j.eneco.2005.09.009.

[12] Worthington A, Kay-Spratley A, Higgs H. Transmission of prices and price volatility in Australian electricity spot markets: a multivariate GARCH analysis. Energy Econ 2005;27:337-50. http://dx.doi.org/10.1016/ j.eneco.2003.11.002.

[13] Higgs H. Modelling price and volatility inter-relationships in the Australian wholesale spot electricity markets. Energy Econ 2009;31:748-56. http:// dx.doi.org/10.1016/j.eneco.2009.05.003.

[14] Haldrup N, Nielsen MØ. A regime switching long memory model for electricity prices. J Econom 2006;135:349-76. http://dx.doi.org/10.1016/ j.jeconom.2005.07.021.

[15] Zachmann G. Electricity wholesale market prices in Europe: convergence?

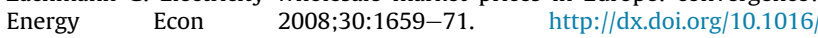
j.eneco.2007.07.002

[16] Bosco B, Parisio L, Pelagatti M, Baldi F. Long-run relations in European electricity prices. J Appl Econom 2010;25:805-32. http://dx.doi.org/10.1002/ jae.1095.

[17] Pellini E. Wholesale spot markets: still a way to go. In: Conf Proceedings, 12th IAEE - Eur Energy Conf; 2012. p. 1-16.

[18] Benatia D, Johnstone N, Haščič I. Effectiveness of policies and strategies to increase the capacity utilisation of intermittent renewable power plants. OECD Environ Work Pap OECD Publ 2013:1-49. http://dx.doi.org/10.1787/ 5k46j0trlrnn-en.

[19] Franco A, Salza P. Strategies for optimal penetration of intermittent renewables in complex energy systems based on techno-operational objectives. Renew Energy 2011;36:743-53. http://dx.doi.org/10.1016 j.renene.2010.07.022.

[20] Söder L, Hofmann L, Orths A, Holttinen H, Wan Y, Tuohy A. Experience from wind integration in some high penetration areas. IEEE Trans Energy Convers 2007;22:4-12. http://dx.doi.org/10.1109/TEC.2006.889604.

[21] Milligan M, Lew D, Corbus D, Piwko R, Miller N, Clark K, et al. Large-scale wind integration studies in the United States: preliminary results. Report, 8th Int Work Large Scale Integr Wind Power Transm Networks Offshore Wind Farms. 2009. p. $1-5$.

[22] Klessmann C, Nabe C, Burges K. Pros and cons of exposing renewables to electricity market risks - a comparison of the market integration approaches in Germany, Spain, and the UK. Energy Policy 2008;36:3646-61. http:/ dx.doi.org/10.1016/j.enpol.2008.06.022.

[23] Sáenz de Miera G, del Río González P, Vizcaíno I. Analysing the impact of renewable electricity support schemes on power prices: the case of wind electricity in Spain. Energy Policy 2008;36:3345-59. http://dx.doi.org/ 10.1016/j.enpol.2008.04.022.

[24] Sensfuß F, Ragwitz M, Genoese M. The merit-order effect: a detailed analysis of the price effect of renewable electricity generation on spot market prices in Germany. Energy Policy 2008;36:3076-84. http://dx.doi.org/10.1016/ j.enpol.2008.03.035.

[25] Amorim F, Martins MVM, Pereira da Silva P. A new perspective to account for renewables impacts in Portugal. In: 2010 7th Int. Conf. Eur. Energy Mark., IEEE; 2010. p. 1-6. http://dx.doi.org/10.1109/EEM.2010.5558695. 
[26] Mauritzen J. What happens when it's windy in Denmark? An empirical analysis of wind power on price volatility in the nordic electricity market. SSRN Electron J 2010:1-29. http://dx.doi.org/10.2139/ssrn.1754931.

[27] Cutler NJ, Boerema ND, MacGill IF, Outhred HR. High penetration wind generation impacts on spot prices in the Australian national electricity market Energy Policy 2011;39:5939-49. http://dx.doi.org/10.1016/ j.enpol.2011.06.053.

[28] Gelabert L, Labandeira X, Linares P. An ex-post analysis of the effect of renewables and cogeneration on Spanish electricity prices. Energy Econ 2011;33:S59-65. http://dx.doi.org/10.1016/j.eneco.2011.07.027.

[29] Cruz A, Muñoz A, Zamora JL, Espínola R. The effect of wind generation and weekday on Spanish electricity spot price forecasting. Electr Power Syst Res 2011;81:1924-35. http://dx.doi.org/10.1016/j.epsr.2011.06.002.

[30] Mulder M, Scholtens B. The impact of renewable energy on electricity prices in the Netherlands. Renew Energy 2013;57:94-100. http://dx.doi.org 10.1016/j.renene.2013.01.025.

[31] Moreno B, López AJ, García-Álvarez MT. The electricity prices in the European Union. The role of renewable energies and regulatory electric market reforms. Energy 2012;48:307-13. http://dx.doi.org/10.1016/j.energy.2012.06.059.

[32] Jónsson T, Pinson P, Madsen H. On the market impact of wind energy forecasts. Energy Econ 2010;32:313-20. http://dx.doi.org/10.1016/ j.eneco.2009.10.018.

[33] Woo CK, Zarnikau J, Moore J, Horowitz I. Wind generation and zonal-market price divergence: evidence from Texas. Energy Policy 2011;39:3928-38. http://dx.doi.org/10.1016/j.enpol.2010.11.046.

[34] Sapio A. The impact of renewables on electricity prices and congestion in a regime switching model: evidence from the Italian grid. 2015. p. 441-51. http://dx.doi.org/10.1007/978-3-319-13881-7_49.

[35] Ardian F, Concettini S, Creti A. Intermittent renewable generation and network congestion: an empirical analysis of Italian Power Market. hal01218543. 2015. p. 1-32.

[36] Figueiredo NC, da Silva PP, Cerqueira PA. Evaluating the market splitting determinants: evidence from the Iberian spot electricity prices. Energy Policy 2015;85:218-34. http://dx.doi.org/10.1016/j.enpol.2015.06.013.

[37] Lund H, Clark WW. Management of fluctuations in wind power and CHP comparing two possible Danish strategies. Energy 2002;27:471-83. http:/ dx.doi.org/10.1016/S0360-5442(01)00098-6.

[38] Danish Energy Agency. Energy policy in Denmark. Report. 2012. p. 30.

[39] Lund H. A green energy plan for Denmark: job creation as a strategy to implement both economic growth and a $\mathrm{CO}_{2}$ reduction. Environ Resour Econ 1999;14:431-9. http://dx.doi.org/10.1023/A:1008344032223.

[40] Danish Energy Authority. A visionary Danish energy policy. Report. 2007. p. 30.

[41] Danish Ministry of Climate Energy and Building. Energy policy report 2013 Report. 2013. p. 1-17.

[42] Lund H. Renewable energy strategies for sustainable development. Energy 2007;32:912-9. http://dx.doi.org/10.1016/j.energy.2006.10.017.

[43] Lund $\mathrm{H}$. The implementation of renewable energy systems. Lessons learned from the Danish case. Energy 2010;35:4003-9. http://dx.doi.org/10.1016/ j.energy.2010.01.036.

[44] Lund H, Hvelplund F, Østergaard PA, Möller B, Mathiesen BV, Karnøe P, et al. System and market integration of wind power in Denmark. Energy Strateg Rev 2013;1:143-56. http://dx.doi.org/10.1016/j.esr.2012.12.003.

[45] Nord Pool. Nord Pool ftp server. 2015.

[46] Danish Parliament. Promotion of renewable energy act. Act No 1392. 2008 p. $1-27$.

[47] Danish Ministry of Transport and Energy. Energy strategy 2025. 2007.

[48] Munksgaard J, Morthorst PE. Wind power in the Danish liberalised power market-Policy measures, price impact and investor incentives. Energy Policy 2008;36:3940-7. http://dx.doi.org/10.1016/j.enpol.2008.07.024.
[49] Edenhofer O, Pichs-Madruga R, Sokona Y, Seyboth K, Kadner S, Zwickel T, et al. Renewable energy sources and climate change mitigation: special report of the intergovernmental panel on climate change. Cambridge University Press; 2011.

[50] MÁ Lynch, Tol RSJ, O'Malley MJ. Optimal interconnection and renewable targets for north-west Europe. Energy Policy 2012;51:605-17. http:// dx.doi.org/10.1016/j.enpol.2012.09.002.

[51] Nicolosi M. Wind power integration and power system flexibility-an empirical analysis of extreme events in Germany under the new negative price regime. Energy Policy 2010;38:7257-68. http://dx.doi.org/10.1016/ j.enpol.2010.08.002.

[52] Batlle C, Pérez-Arriaga IJ, Zambrano-Barragán P. Regulatory design for RES-E support mechanisms: learning curves, market structure, and burdensharing. Energy Policy 2012;41:212-20. http://dx.doi.org/10.1016/ j.enpol.2011.10.039.

[53] MIT Energy Initiative. Report. Managing large-scale penetration of intermittent renewables, 115; 2011. p. 1-240.

[54] World Nuclear Association. Nuclear Energy in Denmark 2015. http://www. world-nuclear.org/info/Country-Profiles/Countries-A-F/Denmark/[accessed 06.03.15].

[55] Eurostat. Eurostat - database 2015. http://ec.europa.eu/eurostat/data/ database [accessed 06.03.15]

[56] Meeus L, Vandezande L, Cole S, Belmans R. Market coupling and the importance of price coordination between power exchanges. Energy 2009;34: 228-34. http://dx.doi.org/10.1016/j.energy.2008.04.013.

[57] Luna L, Martínez J. Impact of wind power generation on the ATC value. In: 17th Power Syst. Comput. Conf; 2011. p. 1-7.

[58] Energinet. Danish Transmission System Operator 2015. http://www. energinet.dk/[accessed 08.03.15].

[59] Amorim F, Pina A, Gerbelová H, Pereira da Silva P, Vasconcelos J, Martins V. Electricity decarbonisation pathways for 2050 in Portugal: a TIMES (The Integrated MARKAL-EFOM System) based approach in closed versus open systems modelling. Energy 2014;69:104-12. http://dx.doi.org/10.1016/ j.energy.2014.01.052.

[60] Mood C. Logistic regression: why we cannot do what we think we can do, and what we can do about it. Eur Sociol Rev 2009;26:67-82. http://dx.doi.org/ 10.1093/esr/jcp006.

[61] Wooldridge J. Econometric analysis of cross section and panel data. second ed. MIT Press; 2010.

[62] Davidson R, Mackinnon JG. Econometric theory and methods. illustrate. Oxford University Press; 2004.

[63] Zeileis A, Koenker R, Doebler P. glmx: generalized linear models extended. R packag version 01-0. 2013. http//CRAN_R-Project_Org/package=Glmx.

[64] Racine JS. Nonparametric econometrics: a primer. Found Trends ${ }^{\mathbb{R}}$ Econom 2007;3:1-88. http://dx.doi.org/10.1561/0800000009.

[65] EPEX. EPEX 2016. www.epexspot.com [accessed 19.01.16].

[66] ENTSO-E. ENTSO-E Transparency Platform 2015. https://transparency.entsoe. eu/[accessed 22.04.15].

[67] Pagan AR, Ullah A. Nonparametric econometrics. Cambridge University Press; 1999.

[68] Hayfield T, Racine JS. Nonparametric econometrics: the np package. J Stat Softw 2008;27:1-32

[69] The R foundation for statistical computing. R. 2014

[70] Li Q Racine JS. Nonparametric econometrics: theory and practice. Princeton University Press; 2007.

[71] Aitchison J, Aitken CGG. Multivariate binary discrimination by the kernel method. Biometrika 1976;63:413-20.

[72] Okumura H, Naito K. Weighted kernel estimators in nonparametric binomial regression. J Nonparametr Stat 2004;16:39-62. http://dx.doi.org/10.1080/ 10485250310001624828. 